\title{
REVIEW OF THE HELMINTHS PARASITIC IN RARE AQUATIC BIRDS IN UKRAINE
}

\author{
O. I. Lisitsyna ${ }^{1,4}$, O. B. Greben ${ }^{1}$, Ya. Yu. Syrota ${ }^{1,2,3,4}$, V. V. Kornyushin ${ }^{1}$ \\ ${ }^{1}$ Schmalhausen Institute of Zoology NAS of Ukraine \\ vul. B. Khmelnytskogo, 15, Kyiv, 01030 Ukraine. Affiliation ID: 60070111 \\ ${ }^{2}$ Kyiv Zoological Park of National Importance, Peremohy Ave, 32, Kyiv, 04116 Ukraine \\ ${ }^{3}$ African Amphibian Conservation Research Group, \\ Unit for Environmental Sciences and Management, North-West University, Potchefstroom, South Africa \\ E-mail: olisitsyna@izan.kiev.ua; goobar4.699@gmail.com \\ ${ }^{4}$ Corresponding author \\ O. I. Lisitsyna (http://orcid 0000-0002-2975-3300) \\ O. B. Greben (http://orcid 0000-0001-9942-2542) \\ Ya. Yu. Syrota (https://orcid.org/0000-0002-8070-9823)
}

Review of the Helminths Parasitic in Rare Aquatic Birds in Ukraine. Lisitsyna, O. I., Greben, O. B., Syrota, Ya. Yu., Kornyushin, V. V. - Helminth fauna of aquatic birds, in general, is well-studied on the territory of Ukraine. However, despite the fact that the data on the helminths of rare aquatic birds are dispersed in numerous faunistic publications, there are no separate reports on this particular group of hosts. The present survey generalizes all available information on the helminths parasitic in rare aquatic birds in Ukraine based on the collection material stored in the Institute of Zoology of NAS of Ukraine and the data from the literature. In Ukraine, the data on helminths diversity is available for 32 species of rare aquatic birds. The diversity is consisting of 295 species including 116 cestodes, 112 trematodes, 53 nematodes, and 14 acanthocephalans. Comparatively higher helminths species diversity was noted in the hosts from Charadriiformes and Anseriformes apparently due to the larger samples' size. On the contrary, small samples of surveyed Falconiformes and Ciconiiformes resulted in a lower diversity of helminths. Most recorded helminth species are generalists infecting wide ranges of hosts. Only ten recorded species are known as species-specific parasites.

Key words: aquatic birds, helminths, rare species. 


\section{Introduction}

Aquatic birds are a large group of birds living on or near bodies of water. One hundred fortyfive species from 9 orders belong to this group in Ukraine (Fesenko, Bokotey, 2002; Jarvis et al., 2014). More of them are common bird species. Thirty-seven species of aquatic birds are rare on the territory of Ukraine (Red Book of Ukraine, 2009). They are seven species from the order Pelecaniformes, one species from the order Ciconiiformes, 11 species from the order Anseriformes, one species from the order Gruiformes, one species from the order Falconiformes and 16 species from the order Charadriiformes. Among them, ten species of the aquatic birds in Ukraine are also in the IUCN Red List (Ieronymidou et al., 2015).

The status of the populations of rare waterfowl is an essential indicator of the aquatic ecosystem condition (Amat and Green, 2010). Usually, rare species of animals are more sensitive to change in the environment than more widespread animals. Different ecological factors impact the numerosity of these species. The most important of them are climate changes (Wormworth, Mallon, 2006; Trautmann, 2018; Mason et al., 2019), environmental pollution (Borghesi et al., 2017), changing of biotopes (Banks, Springer, 1994; Hagy et al., 2014). Helminths of rare aquatic birds are an essential component of healthy ecosystems (Hudson et al., 2006). Helminths are one of the factors in the regulation of the host populations (Kontrimavichus, Atrashkevich, 1982).

In Ukraine, there are no publications specifically considering the helminths of rare aquatic birds. However, numerous articles and monographs contain dispersed data on this subject. The present survey aims at providing a review of the helminth parasitic in rare aquatic birds, giving the information about the range of hosts for helminth species, indicating on pathogenic helminth species, and discussing factors that impact on the circulation of helminths. This study is essential because the rare waterfowl are under the protection of laws, and their prey for any purpose is impossible. Analysis of the parasitological material collected during many years gives the foundation to outline the place of helminths of rare waterfowl in the fauna of helminths of aquatic birds.

\section{Material and methods}

We used two sources of data for the present survey. The first source was the helminthological collection of I. I. Schmalhausen Institute of Zoology. The collection includes samples that have been collected during the last 70 years by scientists from the Institute of Zoology and other Ukrainian scientific institutions. Most of the samples from rare aquatic birds were collected in 1950-1980 by L. O. Smogorzhevskaya, N. I. Iskova, and V. V. Kornyushin. Just several samples were collected after 1980.

The collection includes the helminths collected from 468 individuals of rare aquatic birds of 30 species. Pelecaniformes are presented by 78 birds of 5 species, Anseriformes by 100 birds of 8 species, Charadriiformes by 287 birds of 14 species. Separate helminth samples, each from a single bird specimen, were collected from birds of Gruiformes, Ciconiiformes, and Falconiformes.

The second source of information was the literature data published by Kowalewski (1896), Kholodkovsky (1912), Ciurea (1924, 1930, 1933, 1934), Ivanitsky (1940), Saakova (1952), Gubsky (1957), Leonov (1958), Kovalenko (1962), Srebrodolskaya (1963, 1964), Sergiyenko (1968), Molodan and Kharchenko (1974), Gayevskaya et al. (1975), Smogorzhevskaya (1976), Spasskaya and Spassky (1978), Smogorzhevskaya et al. (1978), Ryzhikov et al. (1985), Iskova (1985), Sharpilo and Iskova (1989), Kornyushin (1992), Iskova et al. (1995), Kornyushin et al. (1996, 1998, 2004, 2011, 2016), and Lisitsyna (2019). Information about helminths of the great white pelican, Pelecanus onocrotalus Linnaeus, 1758 and the pygmy cormorant, Phalacrocorax pygmaeus (Pallas, 1773) are given only according to the literature.

Present survey and analysis cover the information on the helminths of 32 species of birds (table 1) from the territory of Ukraine (fig. 1). Since most previous publications contain no exact geographic coordinates of collection localities, some points on figure 1 show approximately the places of material collection. The map is designed in QGIS (QGIS Development Team, 2019).

\section{Result and discussion}

In total, 295 helminths species were recorded as parasites of rare aquatic birds on the territory of Ukraine, including 116 cestode species, 112 trematode species, 53 nematode species, and 14 acanthocephalan species. The complete list of helminths and corresponding hosts is given in the Appendix (https://www.researchgate.net/ publication/340280083_Review_of_the_helminths_parasitic_in_rare_aquatic_birds_ in_Ukraine_data), the number of helminth species in each host is presented in table 1. Below we give the analysis of helminth diversity and specificity in rare aquatic birds of separate orders. 
Table 1. Representation of helminths of various taxonomic groups in rare aquatic birds of Ukraine

\begin{tabular}{|c|c|c|c|c|c|c|}
\hline $\mathrm{N}$ & Birds species & 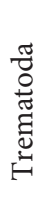 & 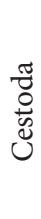 & 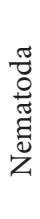 & 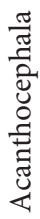 & 营 \\
\hline
\end{tabular}

Pelecaniformes

1. Great white pelican - Pelecanus onocrotalus Linnaeus, $1758 \quad 3 \quad 4 \quad 3 \quad-\quad 15$

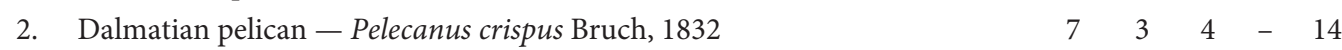

3. Common shag - Phalacrocorax aristotelis (Linnaeus, 1761) $\quad$ 6 $\quad-\quad 4 \quad 1 \quad 11$

4. Pygmy cormorant - Phalacrocorax pygmaeus (Pallas, 1773) $\quad 3 \quad 2 \quad 3-8$

5. Squacco heron - Ardeola ralloides (Scopoli, 1769)

6. Common spoonbill - Platalea leucorodia Linnaeus, 1758

$9 \quad 7 \quad 3-19$

7. Glossy ibis - Plegadis falcinellus (Linnaeus, 1766)

Ciconiiformes

8. Black stork - Ciconia nigra (Linnaeus, 1758) $2-2-4$

Anseriformes

9. Red-breasted goose - Rufibrenta ruficollis (Pallas, 1769)

10. Ruddy shelduck - Tadorna ferruginea (Pallas, 1764)

11. Gadwall - Mareca strepera Linnaeus, 1758

12. Red-crested pochard - Netta rufina (Pallas, 1773)

13. Ferruginous duck - Aythya nyroca (Guldenstadt, 1770)

14. Common goldeneye - Bucephala clangula (Linnaeus, 1758)

15. Common eider - Somateria mollissima (Linnaeus, 1758)

16. Red-breasted merganser - Mergus serrator Linnaeus 1758

Gruiformes

17. Common crane - Grus grus (Linnaeus, 1758) 1

Falconiformes

18. Osprey - Pandion haliaetus (Linnaeus, 1758) $3-3-6$

Charadriiformes

19. Eurasian stone-curlew - Burhinus oedicnemus (Linnaeus, 1758)

\begin{tabular}{ccccc}
- & 1 & - & - & 1 \\
- & 3 & - & - & 3 \\
12 & 24 & 3 & 4 & 43 \\
10 & 15 & 2 & - & 27 \\
12 & 17 & 2 & - & 31 \\
9 & 11 & 4 & 2 & 26 \\
1 & 5 & 2 & - & 8 \\
- & 7 & - & - & 7 \\
18 & 2 & 3 & 1 & 24 \\
1 & - & - & 2 & 3 \\
4 & 6 & 2 & 3 & 15 \\
1 & 3 & - & 3 & 7 \\
19 & 3 & 4 & - & 26 \\
20 & 1 & 4 & - & 25 \\
\hline & & & &
\end{tabular}

20. Common ringed plover - Charadrius hiaticula Linnaeus, 1758

21. Kentish plover - Charadrius alexandrinus (Linnaeus, 1758)

22. Black-winged stilt - Himantopus himantopus (Linnaeus, 1758)

23. Pied avocet - Recurvirostra avosetta Linnaeus, 1758

24. Eurasian oystercatcher - Haematopus ostralegus (Linnaeus, 1758)

25. Marsh sandpiper - Tringa stagnatilis (Bechstein, 1803)

26. Great snipe - Gallinago media (Latham, 1787)

27. Eurasian curlew - Numenius arquata (Linnaeus, 1758)

28. Whimbrel - Numenius phaeopus (Linnaeus, 1758)

29. Collared pratincole - Glareola pratincola (Linnaeus, 1766)

30. Black-winged pratincole - Glareola nordmanni Nordmann, 1842

31. Caspian tern - Hydroprogne caspia (Pallas, 1770)

32. Little tern - Sternula albifrons Pallas, 1764 


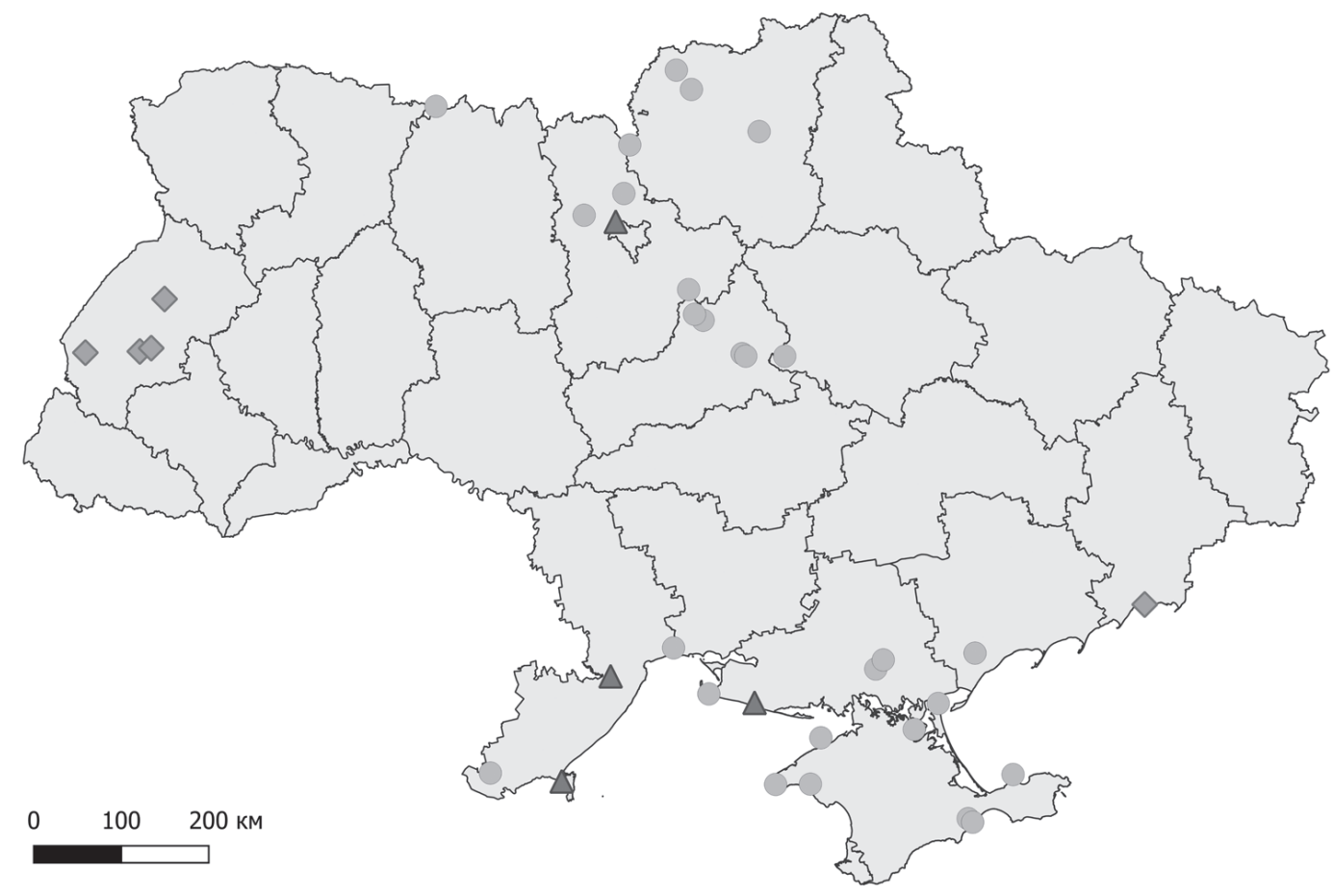

Fig. 1. Localities of the material collection: $\triangle$ - based on collection and literature; - based on collection; - based on literature.

In Charadriiformes, 153 helminth species were found, including 65 cestodes, 59 trematodes, 15 nematodes, and 14 acanthocephalans. Eighty-six species are characteristic of this order: 54 cestodes, 24 trematodes, six nematodes, and two acanthocephalans. Five helminth species are known to parasitize only one host species both in and abroad of Ukraine, namely, Wardium clandestina (Krabbe, 1869) and Plagiorhynchus (Pl.) ponticus Lisitsyna, 1992 are the parasites of Haematopus ostralegus; Lateriporus markevichi Korniushin, 1982 is the parasite of Himantopus himantopus; Wardium ponticum Kornyushin, Georgiev, Greben, 2012 and W. tauricum Kornyushin, Greben, 2010 are the parasites of Glareola pratincole.

In Anseriformes, 99 helminth species were found, including 36 cestodes, 43 trematodes, 17 nematodes, and 3 acanthocephalans. Among those, only 31 species are characteristic of this order: 20 cestodes, 7 trematodes, and four nematodes. Fimbriarioides intermedia (Fuhrmann, 1913) and Microsomacanthus microsoma (Creplin, 1829) are species-specific parasites of Somateria molissima (Kornyushin et al., 1995).

Sixty-three helminth species were found in hosts of the order Pelecaniformes: 19 cestodes, 22 trematodes, 20 nematodes, and 2 acanthocephalans; 27 species, including 12 cestodes, three trematodes, and 12 nematodes, are specific parasites of pelecaniform birds. Four helminth species are species-specific parasites: Acuaria phalacrocoracis (Smogorjewskaya, 1961) parasitizes only Phalacrocorax aristotelis; Choanotaenia plegadis Dubinin et Dubinina, 1940, Proparadilepis plegadissaakovae Kornyushin et Greben, 2015, Oschmarinolepis microcephala (Rudolphi, 1819), and Liga didiplogona Dubinina et Dubinin, 1940 are specific parasites of Plegadis falcinellus.

The osprey, Pandion haliaetus (Linnaeus, 1758) is the only species of rare aquatic birds from the order Falconiformes in Ukraine. The following species of helminths were found 
in this host: Nematostrigea serpens (Nitzsch, 1819), Paracaenogonimus ovatus Katsurada, 1914, Renicola undecima Sudarikov, 1947, Scaphanocephalus expansus Jagerskold, 1903, Porrocaecum angusticole (Mohlin, 1866), and Sexansocara skrjabini Sobolev et Sudarikov, 1939. All these species are parasitic in various diurnal birds of prey, sometimes in birds of other orders (Smogorzhevskaya, 1976).

The only species of rare aquatic birds from the order Ciconiiformes in Ukraine is the black stork, Ciconia nigra (Linnaeus, 1758). The following species of helminths were found in this host: Choanocephalus ferox (Rudolphi, 1795), Tylodelphis excavata (Rudolphi, 1803), Desportesius sagittatus (Rudolphi, 1809), and Dicheilonema ciconiae (Schrank, 1788). All these species are typical parasites of Ciconiiformes (Smogorzhevskaya, 1976, 1990).

The common crane, Grus grus (Linnaeus, 1758) is the only representative of Gruiformes among rare aquatic birds in Ukraine. It was found to be the host of one helminth species, Dispharynx nasuta (Rudolphi, 1819). This helminth is known to have a wide range of hosts belonging to various orders of birds (Smogorzhevskaya, 1976).

Some helminth species found in rare aquatic birds in the present survey are common for hosts belonging to various orders of birds. Below there is the list of helminth species that are known to parasitize comparatively the widest range of hosts - from four orders at least.

Prosthogonimus ovatus (Rudolphi, 1803) is reported from Aythya nyroca, Numenius arquata, and Hydroprogne caspia. The species is normally revealed in Anseriformes, Gruiformes, Pelecaniformes, Podicipediformes, Gaviiformes, Charadriiformes and rarely occurs in Coraciiformes, Strigiformes, Cuculiformes, Apodiformes, Passeriformes (Sharpilo, Iskova, 1989; Iskova et al., 1995).

Cryptocotyle concavum (Creplin, 1825) was found in Pelecanus onocrotalus, Pelecanus crispus, Somateria mollissima, Mergus serrator, Recurvirostra avosetta, Hydroprogne caspia, and Sternula albifrons. The species is known to parasitize hosts from Anseriformes, Pelecaniformes, Gaviiformes, Gruiformes, Podicipediformes, Charadriiformes, and Galliformes (Smogorzhevskaya, 1976).

Echinoparyphium cinctum (Rudolphi, 1802) is reported from Ardeola ralloides (Scopoli, 1769) and Mareca strepera Linnaeus, 1758. The species was previously revealed in Pelecaniformes, Anseriformes, Gruiformes, Charadriiformes, Galliformes, and Coraciiformes (Iskova, 1985).

Prosthogonymus cuneatus (Rud., 1809) is reported from Aythya nyroca, Numenius arquata and Hydroprogne caspia. The species parasitizes hosts from Anseriformes, Podicipediformes, Charadriiformes, Gruiformes and rarely Passeriformes (Sharpilo, Iskova, 1989; Iskova et al., 1995).

Plagiorchis laricola Skrjabin, 1924 was found in Plegadis falcinellus and Numenius arquata. The species was previously revealed in Anseriformes, Charadriiformes, Passeriformes, and birds of prey (Sharpilo, Iskova, 1989).

Mesorchis reynoldi (Bhalerao, 1926) is reported from Mergus serrator and Sternula albifrons. The species parasitizes hosts belonging to Gaviiformes, Pelecaniformes, Anseriformes, and Podicipediformes. It is rarely reported also from Passeriformes (Iskova, 1985; Iskova et al., 1995).

Hypodereum conoideum (Bloch, 1782) was found in Mareca strepera and Aythya nyroca. The species is frequent in Anseriformes, Gruiformes, and Charadriiformes, rare in Columbiformes (Iskova,1985; Iskova et al., 1995).

Digramma interrupta (Rudolphi, 1810) is reported from Pelecanus onocrotalus, Phalacrocorax pygmeus, and Hydroprogne caspia. The species is also known from the hosts belonging to Gaviiformes, Podicipediformes, Anseriformes, diurnal birds of prey, and poultry (Kornyushin, Greben, 2013; Kornyushin et al., 2016). 
Ligula intestinalis (Linneus, 1758) was found in Pelecanus onocrotalus, P. crispus, Phalacrocorax pygmeus, Hydroprogne caspia and Sternula albifrons. It usually parasitizes Pelecaniformes, Gaviiformes, and Podicipediformes, and occasionally Anseriformes and Charadriiformes (Kornyushin et al., 2016).

Polymorphus minutus (Goeze, 1782) was found in Aythya nyroca, Bucephala clangula, and Somateria mollissima. The species is parasitic in Anseriformes, Pelecaniformes, Podicipediformes, Gruiformes, and Charadriiformes. As occasional parasite, it was reported also from Coraciiformes and Passeriformes (Lisitsyna, 2019).

Dispharynx nasuta (Rudolphi, 1819) was found in Mareca strepera and Grus grus. The species parasitizes hosts from Anseriformes, Galliformes, Passeriformes, and diurnal birds of prey (Smogorzhevskaya, 1976, Syrota et al., 2015).

Contracaecum spiculigerum (Rud, 1809) was found in Aythya nyroca and Mergus serrator. The species is a parasite of Anseriformes, Gaviiformes, Podicipediformes, Gruiformes, and Charadriiformes, occasionally of Passeriformes (Smogorzhevskaya, 1976).

Contracaecum rudolphi (Hartwich, 1964) is reported from Pelecanus onocrotalus, Phalacrocorax aristotelis, P. pygmeus, Aythya nyroca, and Mergus serrator. The species was previously revealed in hosts belonging to Anseriformes, Gaviiformes, Charadriiformes, Gruiformes, and, occasionally, Passeriformes (Baruš et al., 1978).

Eustrongylides exisus Jagerskiold, 1909 is reported from Pelecanus crispus, P. onocrotalus and Phalacrocorax pygmeus. This species is known as a parasite of Gaviiformes and Anseriformes (Smogorzhevskaya, 1976).

For most helminth species reported herein, aquatic birds are definitive hosts. Just a few species of rare aquatic birds are known to be paratenic hosts for larval stages of some helminths. Metacercariae of Strigea falconis Szidat, 1928 are found under the skin, in the connective tissue, under the fascia of the muscles in many waterfowl, including rare ones, Pelecanus onocrotalus, Pelecanus crispus, Phalacrocorax aristotelis, Ardeola ralloides, Plegadis falcinellus, Netta rufina, Aythya nyroca, Bucephala clangula and Mergus serrator. The definitive hosts of $S$. falconis are diurnal birds of prey and owls, thus the waterfowl can serve as an additional source of the infection. At the larval stage, the cestode Cysticercus ardeae Dubinin, 1952 may parasitize rare waterfowl: cysticerci of this species were found in the intestinal wall of one specimen of Ardeola ralloides by Smogorzhevskaya (1976). Cysticercus ardeae was described based on the larvae from Plegadis falcinellus, Nycticorax nycticorax, and Ardea cinerea from the Volga delta. Adult stage of the species is unknown. The diurnal birds of prey are presumed to be the definitive hosts of the parasite (Bona, 1975). Dubinin (1952) found cysticerci of C. ardeae in adult storks in spring and the first half of summer, by the end of summer the larvae degenerated. The author suggests, therefore, that infection might have occurred during the host wintering. Larvae of the nematode Gnathostoma pelecani (Chatin, 1874) were found in the muscles of Sternula albifrons (Smogorzhevskaya, 1976). The definitive hosts of this nematode are pelicans. Since S. albifrons is not a part of a diet for the definitive hosts of G. pelecani, the species of bird is an ecological trap ('trap host') for this nematode (Sharpilo, Salamatin, 2005).

Based on available morphological and biological information about the helminths parasitic in rare aquatic birds, we separated several species that are apparently accidental parasites in this host group. For instance, Paricterotaenia porosa (Rudolphi, 1810) was found in Hydroprogne caspia and Recurvirostra avosetta. However, the helminth does not reach maturity in these hosts and should be considered as accidental parasite. Microsomacanthus abortiva (Linstow, 1904) is quite common in Anseriformes and accidentally infects sandpipers, including Haematopus ostralegus, Himantopus himantopus and Recurvirostra avosetta (Kornyushin et al., 1996). Plagiorhynchus (Pr.) cylindraceus (Goeze, 1782 ) is reported in Charadrius alexandrinus, Numenius phaeopus, Glareola pratincola, 
Glareola nordmanni; however, this species of Acanthocephala maturate only in passeriform hosts (Lisitsyna, 2019).

Of 295 species of helminths observed in rare waterfowl of Ukraine, 64 species are often reported in domestic birds, Gallus gallus dom., Numida meleagris dom., Meleagris gallopavo, Anser anser dom. and Anas platyrhynchos dom., goose or chicken. These are 20 species of cestodes, 30 species of trematodes, 11 species of nematodes, and 3 species of acanthocephalans (see Appendix). The intermediate hosts of these helminths are among the most abundant aquatic invertebrates, molluscs of the genera Limnea, Planorbis (Zdun, 1961; Chernogorenko, 1983), freshwater Crustacea of the genera Acanthocyclops, Cyclops, Eucyclops, Mesocyclops, Candona, Cypridopsis, Gammarus (Spasskaya, 1966), leeches of the genera Glossiphonia and Herpobdella (Demshin, 1975), and fishes. These invertebrates are the usual components of waterfowl diet. Therefore, the poultry and widespread waterfowl species, such as Anas platyrhynchos, Anas crecca, Anas querquedula, Fulica atra, Larus ridibundus, Larus cachinnans and etc. may support the loci of the transmission of many helminths in the localities, where rare bird species dwell and feed during migration and nesting.

Some species are pathogenic for waterfowl including rare birds. The intestinal nodular lesions associated with infections by species of Chaunocephalus ferox and Filicollis anatis can lead to debilitation and associated mortality (Santoro et al., 2013; Lisitsyna, 2019). Some species, Echinostoma revolutum (Fröhlich, 1802), Echinoparyphium recurvatum (Linstow, 1873), Cotylurus cornutus (Rud, 1808), Prosthogonymus cuneatus (Rud., 1809), Prosthogonimus ovatus (Rud., 1803), Prosthogonimus rarus (Braun, 1901), Bilharziella polonica (Kowalewsky, 1895), Dicranotaenia coronula (Dujardin, 1845), Diorchis elisae (Skrjabin, 1914), Fimbriaria fasciolaris (Pallas, 1781), Microsomacantus paracompressa (Czaplinski, 1956), Myxolepis collaris (Batsch, 1786), Sobolevicanthus gracilis (Zeder, 1803), Hystrichis tricolor Dujardin, 1845, Echinuria uncinata (Rud., 1819), Streptocara crassicauda (Creplin, 1829), Tetrameres fissispina (Diesing, 1861), Polymorphus minutus (Goeze, 1782), Polymorphus magnus Skrjabin, 1913, are pathogenic for domestic birds (Smogorzhevskaya, 1976). We do not exclude that under certain conditions these helminths can be pathogenic for rare water birds.

\section{Conclusions}

The species richness of helminths in rare aquatic birds is high, including about half of all helminth species of aquatic birds from Ukraine. On the other hand, only 10 helminth species may be considered as species-specific parasites of this host group. Some helminths of rare aquatic birds can be pathogenic for domestic waterfowl. The transmission of other helminths can be supported by aquatic birds that are more or less common. It is apparent, therefore, that the helminth communities of rare aquatic birds are not isolated from the helminth communities of common and widespread aquatic birds. So we conclude that it is possible to get quite confident data on helminth diversity of the rare aquatic birds based on researching samples of common birds within a particular territory.

\section{References}

Amat, J. A., Green, A. J. 2010. Waterbirds as Bioindicators of Environmental Conditions. In: Hurford, C. et al., eds. Biological Monitoring in Freshwater Habitats, 45-52. doi: 10.1007/978-1-4020-9278-7_5

Banks, R. C., Springer, P. F. 1994. A Century of population trends of waterfowl in Western North America. Studies in Avian Biology, 15, 134-1 46.

Baruš, V., Sergeeva, T. P., Sonin, M. D., Ryzhikov, K. M. 1978. Helminths of Fish-Eating Birds of the Palaearctica Region. I. Springer-Science+Business Media. B. V., 1-318. 
Bona, F. V. 1975. Etude critique et taxonomique des Dilepididae Fuhrm., 1907 (Cestoda) parasites des Ciconiiformes. Considérations sur la spécificité et la spéciation. Monitore zoologico italiano. Publication ayant bénéficié d'un subside du "Consiglio Nazionale delle Ricerche”, Roma, 1-750.

Borghesi1, F., Dinelli1, E., Migani, F., Bechet, A., Rendon-Martos, M., Amat, J. A., Sommer, S., Gillingham, M. A. F. 2017. Assessing environmental pollution in birds: a new methodological approach for interpreting bioaccumulation of trace elements in feather shafts using geochemical sediment data. Methods in Ecology and Evolution, 8, 96-108. doi: 10.1111/2041-210X.12644.

Chernogorenko, M. I. 1983. Larval trematodes in molluscs of the Dnieper River and its reservoirs. Naukova dumka, Kyiv, 1-212 [In Russian].

Ciurea, I. 1924. Hétérophyides de la Faune Parasitaire de la Roumanie. Parasitology, 16 (1), $1-21$.

Ciurea, I. 1930. Contribution à l'etude morphologique et biologique de quelques strigeides des oiseaux ichthyophages de la faune de Romanie (Recherches experimental). Arch. Roumaines. Pathol. Expér. et Microbiol., 3 (3), 227-323.

Ciurea, I. 1933. Les vers parasitaires de I'homme, des mammiferes et des oiseaux provenant des poissons du Danube et de la mer Noire. Premier memoire. Trematodes, famille Heterophyidae Odhner, avec un essai de Classification des trematodes de la Superfamille. Arch. Roumain. Pathol, Expér. et Microbiol., 6, $150-171$.

Ciurea, I. 1934. Recherches expérimentales sur la réceptivité des oiseaux domestiques à l'infestation par les trématodes de la famillie Heherophyidae Odhner. In: Livre homage mémoire. Prof. Cantacuzéne. Paris, 169-183.

Demshin, N. I. 1975. Oligochaeta and Hirudinea as intermediate hosts of helminthes. Nauka, Novosibirsk, 1-192 [In Russian].

Dubinin, V. B. 1952. The parasitic worm larvae of vertebrate animals of the Volga River delta. Parasit. Sb. Zool. Inst AN SSSR. 14, 213-265 [In Russian].

Fesenko, G. V., Bokotey A. A. 2002. Bird fauna of Ukraine: Field guide. Kyiv, 1-416 [In Ukrainian].

Gayevskaya, A. V., Gusev, A. V., Delyamure, S. L., Donec, Z. S., Iskova, N. I., Kornyushin, V. V., Margaritov, N. M., Markevich, A. P., Mordvinova, T. N., Naydenova, N. N., Nikolaeva, V. M., Parukhin, A. M., Pogorelceva, T. P., Smogorzhevskaya, L. A., Solonchenko, A. I., Shtein, G. A., Shulman, S. S. 1975. Key to the parasites of vertebrates of the Black Sea and Sea of Azov. Parasitic invertebrates of fishes, fish-eating birds and marine animals. Naukova dumka, Kyiv, 1-551 [In Russian].

Gubsky, V. S. 1957. Materials on the helminth fauna of hunting-industrial birds of the Lower Dniester. Proceedings of the Odessa University, 147 (8), 171-179 [In Russian].

Hagy, H. M. et al. 2014. Wetland issues affecting waterfowl conservation in North America. Wildfowl. Special Issue 4, 343-367.

Hudson, P. J., Dobson, A. P., Lafferty, K. D. 2006. Is a healthy ecosystem one that is rich in parasites? Trends in Ecology and Evolution, 21 (7), 381-385.

Ieronymidou, C., Pople, R., Burfield I., Ramirez, I. 2015. The European Red List of Birds 2015. Luxembourg: Office for Official Publications of the European Communities Bird Census News, 28/1, 3-19.

Iskova, N. I. 1985. Fauna of Ukraine, Vol. 34. issue 4. Trematodes. Echinostomatata. Naukova dumka, Kiev, 1-223 [In Russian].

Iskova, N. I., Sharpilo, V. P., Sharpilo, L. D., Tkach, V. V. 1995. Catalogue of the helminths of Ukrainian vertebrates. Trematodes of terrestrial vertebrates. Kiev, 1-93 [In Russian].

Ivanitsky, S. V., 1940. Materials on the helminth fauna of vertebrates from Ukraine (fauna of cestodes, nematodes, and acanthocephalans). Proceedings of the Kharkov Veterinary Institute, 19, 129-154 [In Russian].

Jarvis, E. D. et al., 2014. Whole-genome analyses resolve early branches in the tree of life of modern birds. Science, 346, 1320-1331. doi.org/10.1126/science.1253451

Kholodkovsky, N. A. 1912. Explanatory catalogue of the collection of parasitic worms of the Zoological Cabinet of the Military Medical Academy. 1. Petersburg, 68-85 [In Russian].

Kontrimavichus, V. L., Atrashkevich, G. I. 1982. Parasitic systems and their role in the population biology of helminths. Parasitology, 16 (3), 177-187 [In Russian].

Kornyushin, V. V. 1992. Bird cestodes of the south of Eastern Europe (systematics, structure and features of fauna formation, chronology, ecology). Abstract of the doctoral dissertation. Kyiv, 1-69 [In Russian].

Kornyushin, V. V., Greben, O. B. 2013. Cestode fauna of gulls birds in the Black Sea Biosphere Reserve. Prirodnichy Almanah, Biologichni nauki, Kherson, 18, 25-38 [In Russian].

Kornyushin, V. V., Greben, O. B., Korol, E. N. 2016. Role of the Great Cormorant, Phalacrocorax carbo, in the helminth circulation in colonies of fish-eating and other hydrophilic birds in southern Ukraine. Vestnik Zoologii, supplement 34, 195-210 [In Russian].

Kornyushin, V. V., Iskova, N. I., Smogorzshevskaia, L. A., Ardamatskaia, T. B. 1996. The helminth fauna structure of the isolated Black Sea population of common eider (Somateria mollissima). - Parasitology in the Ukraine. Yesterday, Today and Tomorrow. Proceedings of the Jubilee Conference of USSP, 16-17th of May, 1995. Kyiv, 39-49 [In Russian]. 
Kornyushin, V. V., Sergienko, M. I., Kaprus, I. Ya., Rukavec, S. V. 2011. Collection of birds cestodes in the holding of the State Museum of Natural History. Scientific notes of the State Museum of Natural History, 27, 37-50 [In Russian].

Kornyushin, V. V., Smogorzhevskaya, L. A., Iskova, N. I. 2004. Circulation of helminthes in colonies of Pelicaniformes and Ciconiiformes in the south of Ukraine. Collection of scientific works of the Azov-Black Sea Ornithological Station, 7, 241-276 [In Russian].

Kornyushin, V. V., Smogorzhevskaya, L. A., Iskova, N. I. 1998. Helminth fauna of birds from zoo and arboretum from the Askania-Nova Nature Reserve. Proceedings of the International scientific conference on the 100th anniversary of the Ascanian steppe reserve. Askania Nova, 49-52 [In Russian].

Kovalenko, I. I. 1962. A study of the biology of pathogens of some helminthiases of domestic ducks of the Azov coast, and the issues of epizootology and prevention. Abstract of Ph. D. thesis. Kharkiv, 1-22 [In Russian].

Kowalewski, M. 1896. Materyaly do fauny helmintologicznej pasorzytniczei polskiej I et II. Spraw. Kom. Phyzyogr. Acad. Um. Krakow, 31, 251-258.

Leonov, V. A. 1958. Helminth fauna of gulls of the Black Sea Reserve and the adjacent territory of the Kherson region. Scientific Notes of the Gorky Pedagogical Institute, 20, 266-296 [In Russian].

Lisitsyna, O. I. 2019. Fauna of Ukraine, Vol. 31. Acanthocephala. Naukova dumka, Kyiv, 1-223 [In Russian].

Mason, L. R. et al. 2019. Population responses of bird populations to climate change on two continents vary with species' ecological traits but not with direction of change in climate suitability. Climatic Change, 157, 337-354.

Molodan, G. N., Kharchenko, V. I. 1974. Helminths of birds in the wetland complex of the Sea of Azov. Bulletin of the All-Union Institute of Helminthology K. I. Scriabin, 14, 84 [In Russian].

QGIS Development Team. 2019. QGIS Geographic Information System. Open Source Geospatial Foundation Project. http://qgis.osgeo.org

Red Book of Ukraine. 2009. Animals / Ed. I. A. Akimov. Globalconsulting, Kyiv, 398-484 [In Ukrainian].

Ryzhikov, K. M., Ryšavý, B., Khokhlova, I. G., Tolkacheva, L. M., Kornyushin, V. V. 1985. Helminths of fish-eating birds of the Palaearctic region II. USSR academy of science, Helminthological Laboratory, Czechoslovak Academy of Sciences. Moscow. Prague, Institute of Parasitology, 1-411 [In Russian].

Saakova, E. O. 1952. Fauna of parasitic worms of birds in the Danube Delta. Abstract of Ph. D. thesis. Leningrad, 1-9 [In Russian].

Santoro, M., Degli Uberti, B., Galiero, G., Di Prisco, F., D’Alessio, N., Veneziano, V. 2013. Chaunocephalus ferox (Digenea: Echinostomatidae) infection associated with fatal cachexia in a white stork (Ciconia alba). Helminthologia, 50 (3), 181-184.

Sergiyenko, M. I. 1968. Fauna of flat and round worms of waterfowl of the Upper Dniester basin. Abstract of Ph. D. thesis. Lviv, 1-26 [In Russian].

Sharpilo, V. P., Iskova, N. I. 1989. Fauna of Ukraine, Vol. 34. issue 3. Trematodes. Plagiorchiata. Naukova dumka, Kiev, 1-278 [In Russian].

Sharpilo, V. P., Salamatin, R. V. 2005. Paratenic parasitism: Origins and Development of the concept. Kyiv, 1-238 [In Russian].

Smogorzhevskaya, L. A. 1976. Helminths of aquatic and marsh birds of the fauna of Ukraine. Naukova dumka, Kyiv, 1-416 [In Russian].

Smogorzhevskaya, L. A. 1990. Fauna of Ukraine, Vol. 32. issue 3. Nematodes. Acuarioidea. Naukova dumka, Kiev, 1-188 [In Russian].

Smogorzhevskaya, L. A., Iskova, N. I., Kornyushin, V. V., Shalimova, A. N. 1978. The materials on parasitic helminths of birds from Black Sea State Reserve. In: 50 Years of the Black Sea State Reserve. Naukova dumka, Kyiv, 141-152 [In Russian].

Spasskaya, L. P. 1966. Cestodes of birds of the USSR. Hymenolepididae. Nauka, Moscow, 1-700 [In Russian].

Spasskaya, L. P., Spassky, A. A. 1978. Cestodes of birds of the USSR. Dilepididae of limnophilic birds. Nauka, Moscow, 1-315 [In Russian].

Srebrodolskaya, N. I. 1963. Materials on parasitofauna of Anseriformes from West Ukrainian Polissya (first message). Proceeding of works of PhD students of Lviv University. Natural Sciences. Lviv, 92-98 [In Russian].

Srebrodolskaya, N. I. 1964. Waterfowl and swamp birds of the western part of Ukrainian Polissia. Abstract of Ph. D. thesis. Lviv, 1-22 [In Russian].

Syrota, Y. Y., Kharchenko, V. O., Lyaskivskiy, V. N., Kobylinsky, V. V., Vasylkivska, I. B. 2015. Finding of Two Species from the Tribe Synhimantea (Nematoda, Acuariidae) in the Kyiv Zoological Park. Vestnik Zoologii, 49, 483-488. doi.org/10. 1515/vzoo-2015-0059.

Trautmann, S. 2018. Climate Change Impacts on Bird Species. In: Tietze, D. T., ed. Bird Species. Fascinating Life Sciences. Springer, Cham. 217-234. doi.org/10.1007/978-3-319-91689-7_12. 
Wormworth, J., Mallon, K. 2006.Bird species and climate change: the global statusreport version 1.0. www.climaterisk.com.ua/wpcontent/uploads/2006/CR_Report_BirdSpeciesClimateChange.pdf (15 March 2009).

Zdun, V. I. 1961. Larvae of trematodes in freshwater molluscs in Ukraine. AN URSR, Kyiv, 1-141 [In Ukrainian].

Received 28 February 2020

Acceped 24 April 2020 